\title{
The monocyte chemotactic protein 1 (MCP-1) and interleukin 8 (IL-8) in Hodgkin's disease and in solid tumours
}

\author{
M G Luciani, A Stoppacciaro, G Peri, A Mantovani, L P Ruco
}

\begin{abstract}
Aims-Monocyte chemotactic protein 1 (MCP-1) and interleukin 8 (IL-8) are small, inducible proteins with chemotactic activity for specific subsets of leucocytes. The possibility that MCP-1 and IL-8 are produced in tissues involved by Hodgkin's disease, thus contributing to the inflammatory-type background of the lesion, was investigated.

Methods-The presence of RNA transcripts for MCP-1 and IL-8 was investigated in biopsy samples of 24 cases of Hodgkin's disease, 17 non-Hodgkin's malignant lymphomas, 30 solid tumours, and 30 histologically normal tissues by means of reverse transcription-polymerase chain reaction (RT-PCR)/Southern blot analysis.

Results-MCP-1 expression was detected in 23 of 24 cases of Hodgkin's disease, in seven of 17 cases of $B$ cell non-Hodgkin's lymphoma, and in seven of 14 cases of reactive lymphoid hyperplasia. IL-8 was present in six of 14 cases of Hodgkin's disease, and was seen only rarely in $B$ cell non-Hodgkin's lymphoma and in reactive lymphoid tissues. MCP-1 and IL-8 RNA transcripts were detected in 13 of 25 carcinomas originating from the lung, breast, thyroid, and ovary.

Conclusions-These findings are consistent with the possibility that MCP-1 and IL-8 are two additional cytokines involved in the pathogenesis of Hodgkin's disease.
\end{abstract} (f Clin Pathol: Mol Pathol 1998;51:273-276)

Keywords: monocyte chemotactic protein 1, interleukin 8 , Hodgkin's disease, solid tumours

Medicina

Sperimentale e

Patologia, Università

"La Sapienza", Viale

Regina Elena 324,

00161 Roma, Italy

M G Luciani

A Stoppacciaro

L P Ruco

Istituto di Ricerche

Farmacologiche

"Mario Negri",

Milano, Italy

G Peri

A Mantovani

Correspondence to: Dr Ruco.

email: ruco@uniroma1.it

Accepted for publication 21 July 1998
Interleukin 8 (IL-8) and monocyte chemotactic protein 1 (MCP-1) are the most representative members of $\alpha$ and $\beta$ chemokines, respec- tively. Chemokines are produced by leucocytes, ${ }^{34}$ endothelial cells, ${ }^{5}$ epithelial cells, ${ }^{67}$ and fibroblasts ${ }^{89}$ in inflamed tissues, during reparative fibrosis, and in tumours. Their secretion is induced by endogenous and exogenous factors such as mitogens, bacterial lipopolysaccharide (LPS) and the proinflammatory cytokines IL-1 and tumour necrosis factor $\alpha(\mathrm{TNF}-\alpha) \cdot{ }^{10-12}$ Once produced, chemokines act on circulating leucocytes in three ways, namely: ${ }^{2}(1)$ they make leucocytes adhere to vascular endothelium by activating leucocyte integrins, (2) they facilitate cell extravasation by creating a chemotactic gradient, and (3) they cause leucocyte activation. IL-8 mainly attracts neutrophils, whereas MCP-1 is predominantly active on monocytes and basophils.

Chemokine production has been investigated in some pathological conditions including atherosclerosis, ${ }^{13}$ pulmonary fibrosis, ${ }^{14}{ }^{15}$ acute and chronic inflammatory diseases, ${ }^{16-19}$ solid tumours, ${ }^{20-23}$ and malignant lymphomas. $^{24} 25$ In our study, we investigated the presence of RNA transcripts for MCP-1 and IL-8 in 138 tissue biopsies, including 41 cases of malignant lymphoma and 30 solid tumours.

\section{Materials and methods}

RNA EXTRACTION AND NORTHERN BLOT ANALYSIS Fragments of 138 fresh tissue biopsies were embedded in optimal cryopreserving tissue (OCT) compound (Miles, Elkhart, Indiana, USA), snap frozen in liquid nitrogen, and stored at $-80^{\circ} \mathrm{C}$ until use. Total RNA was extracted from 30-50 cryostat sections $(\sim 10 \mathrm{mg})$ using RNAfast (Molecular Systems, San Diego, California, USA), according to the manufacturer's protocol. RNA from endotoxin stimulated (25 ng/ml LPS) peripheral blood leucocytes of healthy donors was used as a positive control.

Aliquots of $15-20 \mu \mathrm{g}$ of each RNA sample were used for northern blot analysis. Briefly, the RNA samples were suspended in $0.5 \times 3-$ morpholinopropanesulphonic acid (MOPS)/ ethylenediamine tetra acetic acid (EDTA) buffer, $2.2 \mathrm{M}$ formaldehyde, and $12.5 \mathrm{mM}$ formamide. They were then denatured at $65^{\circ} \mathrm{C}$ for 15 minutes, electrophoresed under denaturing conditions ( $1 \%$ agarose gel, $1 \times$ MOPSEDTA buffer, $2.2 \mathrm{M}$ formaldehyde), and transferred on to a nylon membrane (Qiabrane; Quiagene, Valencia, California, USA).

$\beta$-Globin obtained from the polymerase chain reaction (PCR), $0.7 \mathrm{~kb}$ MCP-1 cDNA, ${ }^{26}$ and $0.416 \mathrm{~kb} \mathrm{IL}-8^{12} \mathrm{cDNA}$ were labelled with 


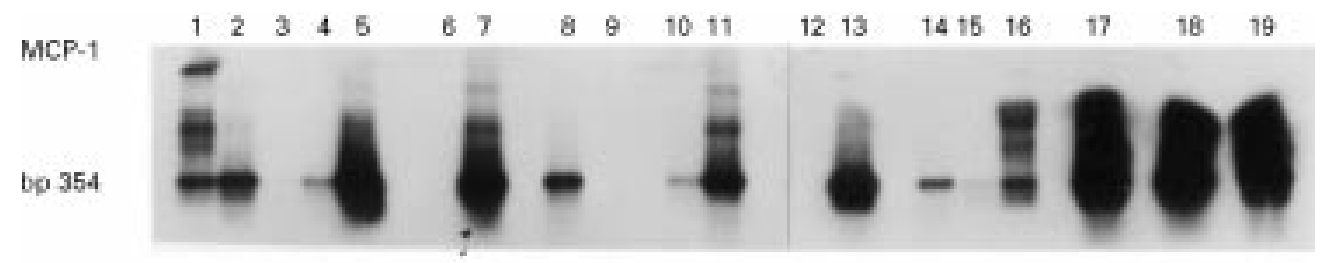

B-Globin

bp 256

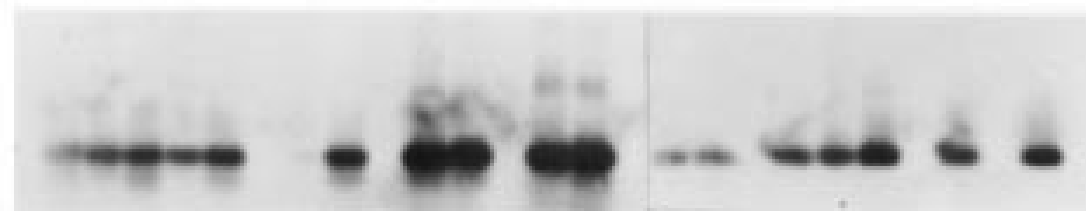

Figure 1 Southern blot/RT-PCR amplification for MCP-1 of RNA obtained from tissues involved by Hodgkin's disease and other pathological conditions. Aliquots of $25 \mu \mathrm{l}$ of PCR product were electrophoresed through a $2 \%$ agarose gel, transferred on to a Qiabrane membrane and hybridised with the specific ${ }^{32} P$ labelled probe. Lanes 1-5, Hodgkin's disease; lanes 6 and 7, non-Hodgkin's lymphomas; lanes 8 and 9, granulomatosis; lanes 10 and 11, lymphoid hyperplasia; lanes 12 and 13, chronic inflammatory diseases; lanes 14-16, lung carcinomas; lanes 17-19, four, eight, and 24 hour lipopolysaccharide stimulated macrophages. In all cases, $\beta$-globin hybridisation was used as a positive control for RNA extraction.

${ }^{32}$ PdCTP using the random primers method (Multiprime DNA labelling kit; Amersham Life Sciences, Amersham, Buckinghamshire, $\mathrm{UK})$. The membranes were prehybridised for one hour at $42^{\circ} \mathrm{C}$, then hybridised at $50-55^{\circ} \mathrm{C}$ overnight with $5 \times 10^{6}$ counts/minute $/ \mathrm{ml}$ of each probe in 5-10 $\mathrm{ml}$ of Quickhyb hybridisation solution (Stratagene, La Jolla, California, USA) containing $11 \mu \mathrm{g} / \mathrm{ml}$ salmon sperm DNA (Sigma, St Louis, Missouri, USA). Stringency washes were performed as follows: $2 \times$ saline sodium citrate (SSC), $0.5 \%$ sodium dodecyl sulphate (SDS) for 15 minutes at room temperature, $0.1 \times \mathrm{SSC}, 0.5 \% \mathrm{SDS}$ at $37^{\circ} \mathrm{C}$ for 30 minutes, $0.1 \times \mathrm{SSC}$, and $0.5 \% \mathrm{SDS}$ at $60^{\circ} \mathrm{C}$ for one hour. Finally, the membranes were exposed to $x$ ray films at $-80^{\circ} \mathrm{C}$ for $24-48$ hours.

REVERSE TRANSCRIPTION-PCR (RT-PCR)

First strand cDNA was synthesised from $10 \mu \mathrm{g}$ total RNA using Moloney murine leukaemia virus (M-MLV) reverse transcriptase (Promega Corporation, Madison, Wisconsin, USA) ) for one hour at $42^{\circ} \mathrm{C}$. An aliquot of $1 \mu \mathrm{g} \mathrm{cDNA}$ from each sample was amplified by PCR using a taq DNA polymerase and the following

Table 1 Monocyte chemotactic protein 1 (MCP-1) and interleukin 8 (IL-8) in normal tissues and in pathological conditions

\begin{tabular}{|c|c|c|c|c|}
\hline \multirow[b]{2}{*}{ Histology } & \multicolumn{2}{|l|}{$M C P-1$} & \multicolumn{2}{|l|}{$I L-8$} \\
\hline & $P C R-S B$ & $N B$ & $P C R-S B$ & $N B$ \\
\hline Normal tissues ${ }^{\star}$ & $1 / 30$ & ND & $1 / 28$ & ND \\
\hline Hodgkin's disease (nodular sclerosis) & $13 / 14$ & $0 / 3$ & $3 / 7$ & $0 / 3$ \\
\hline Hodgkin's disease (mixed cellurlarity) & $8 / 8$ & $0 / 1$ & $3 / 6$ & $0 / 1$ \\
\hline Hodgkin's disease (lymphocyte predominance) & $2 / 2$ & $0 / 1$ & $0 / 1$ & $0 / 1$ \\
\hline B cell lymphoma & $7 / 17$ & $0 / 2$ & $0 / 6$ & $0 / 2$ \\
\hline Granulomatosis and chronic inflammatory diseases $\ddagger$ & $16 / 23$ & $0 / 4$ & $6 / 18$ & $0 / 7$ \\
\hline Lymphoid hyperplasia & $7 / 14$ & $0 / 2$ & $2 / 6$ & ND \\
\hline Carcinoma $\$$ & $14 / 26$ & $0 / 3$ & $13 / 25$ & ND \\
\hline Malignant mesothelioma & $1 / 1$ & ND & $1 / 1$ & ND \\
\hline Thymoma & $1 / 3$ & ND & $0 / 3$ & ND \\
\hline
\end{tabular}

The presence of IL-8 and MCP-1 mRNA was investigated in samples of cryopreserved fresh tissues. MCP-1 and IL-8 RNA transcripts were detected using RT-PCR/Southern blot or northern blot analysis of total RNA.

$\star$ Biopsies of pulmonary parenchyma (2), non-metastatic lymph node (2), stomach (1), liver (1), thymus (2) thyroid (2), breast (2), and skin (18).

†Small cell (5), centroblastic/centrocytic (5), and large cell B cell lymphomas (7).

$\ddagger$ Tubercular lesions (5), sarcoidosis (4), non-specific chronic inflammatory infiltrates (4), chronic

dermatitis (4), Crohn's disease (4), and granulomas of different origin (2).

§Lung (10), thyroid (4), ovary (1), larynx (1), bladder (1), and breast (9) carcinomas.

$\mathrm{NB}$, northern blot; ND, not determined; PCR-SB, PCR-Southern blot. specific primers; MCP-1 forward primer: 5'-CTC AGC CAG ATG CAA TCA ATG C-3' (bases 68-89); MCP-1 reverse primer: 5'-CCT CAA GTC TTC GGA GTT TGG G-3' (bases 280-302) (kindly provided by A Mantovani, Milan, Italy); IL-8 forward primer: 5'-ATG ACT TCC AAG CTG GCC GTC CT-3' (bases 103-127); IL-8 reverse primer: 5'-TCT CAG CCC TCT TCA AAA ACT TCT C-3' (bases 369-393); $\beta$-globin forward primer: 5'-CAA CTT CAT CCA CGT TCA CC-3' (bases 54-73); and $\beta$-globin reverse primer: 5'-GAA GAG CCA AGG ACA GGT AC-3' (bases 295-276). The PCR was carried out in a $50 \mu$ volume $(1.5 \mathrm{mM} \mathrm{MgCl}, 1 \mathrm{U}$ Taq DNA polymerase, and $1 \mu \mathrm{M}$ primers) for 30 cycles (one minute denaturation at $94^{\circ} \mathrm{C}$, one minute annealing at $60^{\circ} \mathrm{C}$, and one minute extension at $72^{\circ} \mathrm{C}$ ) using a Perkin Elmer GeneAmp PCR System 9600 thermocycler (Perkin Elmer Cetus, Norwalk, Connecticut, USA).

An aliquot of $25 \mu \mathrm{l}$ of each PCR product was analysed on a $2 \%$ agarose gel. The PCR products were transferred on to a nylon membrane (Qiabrane; Quiagene) in $0.4 \mathrm{M} \mathrm{NaOH}$, and their specificity was controlled by Southern blot analysis.

\section{Results}

The presence of MCP-1 and IL-8 was investigated with RT-PCR/Southern blot in 41 cases of malignant lymphoma and in 30 solid tumours (fig 1 and table 1). MCP-1 was detected in 23 of 24 cases of Hodgkin's disease, in seven of 17 cases of B cell non-Hodgkin's lymphoma, and in seven of 14 cases of reactive lymphoid hyperplasia (table 1). IL-8 was present in six of 14 cases of Hodgkin's disease, and was seen only rarely in B cell nonHodgkin's lymphoma and in reactive lymphoid tissues. Hodgkin's disease was the pathological condition characterised by the highest incidence of cases positive for chemokine RNA molecules, even when compared with 23 cases of granulomatous and non-granulomatous chronic inflammatory diseases. MCP-1 and IL-8 RNA transcripts were detected to the same extent in nodular sclerosis and in mixed cellularity cases. A clear band of PCR amplification was seen in 
$80-100 \%$ of cases before Southern blot hybridisation. However, and in spite of the high frequency of PCR positive cases, MCP-1 and/or IL-8 mRNA molecules were difficult to demonstrate by northern blot analysis. No reactivity was seen when 15-20 ng total RNA were used (table 1). In further experiments performed with 30-35 ng total RNA, a weak reaction for MCP-1 was detected in three of six PCR positive Hodgkin's disease samples, and in five of eight PCR positive granulomatous disease samples. A strong reaction was obtained with total RNA extracted from LPS stimulated macrophages used as a positive control. For comparison, the presence of MCP-1 and IL- 8 RNA transcripts was also investigated in solid tumours and in normal tissues. Either one or both of the chemokines were detected in about half of the 26 carcinomas originating from lung, breast, thyroid, and ovary, and in only one (lung tissue) of 30 samples of histologically normal tissues.

\section{Discussion}

In our study, we provide the first evidence that MCP-1 RNA transcripts can be detected in most cases of classic Hodgkin's disease, and we confirm a previous study showing that IL- 8 RNA is present in more than half of all cases of Hodgkin's disease, but is rarely detected in non-Hodgkin's lymphomas. ${ }^{25} \mathrm{MCP}-1$ and IL-8 can be produced by neoplastic Hodgkin/ReedSternberg cells and/or by lesional reactive cells. Using in situ hybridisation, Foss and colleagues ${ }^{25}$ have shown that IL- 8 RNA is seen only rarely in Hodgkin/Reed-Sternberg cells (three of 33 cases), whereas it is detected frequently in lesional reactive cells including macrophages, neutrophils, and mesenchymal cells (20 of 33 cases). IL- 8 positive cells were more numerous in cases of nodular sclerosis, and showed a weak positive correlation with the density of neutrophils. Attempts to demonstrate IL-8 at the protein level by means of immunohistochemistry were described as inconclusive because the staining was unreliable. Unfortunately, we had a similar experience with four different anti-MCP-1 mouse monoclonal antibodies, which were not effective in visualising MCP-1 positive cells in frozen or in paraffin wax embedded sections, even when different fixation or immunostaining procedures were used (data not shown). This evidence, together with the observation that MCP-1 and IL-8 RNA transcripts were difficult to demonstrate with northern blot analysis, suggest that the two chemokines are produced in limited amounts in Hodgkin's disease. Nevertheless, it seems reasonable to postulate that MCP-1 and IL-8 help determine the inflammatory-type background typical of Hodgkin's disease. This interpretation is also supported by the observation that the highest percentages of MCP-1 positive and/or IL-8 positive cases were detected in those pathological conditions associated with prominent inflammatory reactions.

In previous studies, we have provided evidence that cytokine induced activation of vascular endothelium is involved in the patho- genesis of Hodgkin's disease. It was shown that Hodgkin/Reed-Sternberg cells and reactive macrophages produce the pro-inflammatory cytokines IL-1 and TNF- $\alpha$, which in turn induce activation of vascular endothelium. ${ }^{27}{ }^{28}$ It was then shown that numerous activated blood vessels of Hodgkin's disease lesions are reactive for the adhesion molecules E-selectin, intercellular adhesion molecule 1 (ICAM-1), vascular cell adhesion molecule 1 (VCAM-1) and CD31/platelet endothelial cell adhesion molecule (PECAM), so that they are potentially responsible for a prominent recruitment of circulating leucocytes into the lesion. ${ }^{29}$ Leucocyte migration is a multistep process in which attachment and rolling of leucocytes to the activated endothelium is followed by other events, including triggering of leucocyte adhesiveness, leucocyte arrest, and transendothelial migration. ${ }^{30}$ This multistep process requires expression of adhesion molecules on activated endothelial cells, but it is also dependent on chemokine release. Our findings raise the possibility that MCP-1 and/or IL- 8 increase leucocyte adhesiveness to the endothelium, perhaps acting via $\mathrm{G}$ protein coupled receptors, and provide chemotactic gradients that direct leucocyte movement into Hodgkin's disease lesions. ${ }^{31-33}$

MCP-1 and/or IL-8 RNA transcripts were detected by us in about half of the solid tumours tested. It has been reported previously that MCP-1 and IL- 8 are released into culture supernatants by tumour cells, and can be detected in tumour specimens of melanoma, astrocytoma, histiocytoma, and mesothelioma. ${ }^{2021}$ In some of these studies it was shown that tumour cells and host stromal cells are both active in chemokine production. ${ }^{34-36}$ The ultimate result of intratumoral chemokine release on tumour progression is difficult to predict. In fact, chemokines might attract leucocytes that can be effective in contrasting tumour cell growth; in other cases, and as recently demonstrated in lung bronchoalveolar carcinomas, IL-8 induced intratumoral neutrophil infiltration might be associated with a worse prognosis. ${ }^{22}$ A further complication derives from the potential angiogenic activity of IL-8, and its influence on tumour vascularisation. Evidence supporting the existence of IL-8 mediated angiogenesis was obtained recently in gastric carcinoma, where it was shown that intratumoral microvessel density correlated positively with IL-8 production. ${ }^{23}$

This work was supported by a grant from Associazione Italiana Ricerca sul Cancro (AIRC).

1 Baggiolini M, Dewald B. Moser B. Human chemokines: an update. Annu Rev Immunol 1997;15:675-705.

2 Furie MB, Randolph GJ. Chemokines and tissue injury. $\mathrm{Am}$ f Pathol 1995;146:1287-301.

3 Colotta F, Borré A, Wang MJ, et al. Expression of monocyte chemotactic cytokine by human mononuclear phagocytes. f Immunol 1992;148:760-5.

4 Liebler JM, Kunkel SL, Burdick MD, et al. Production of IL-8 and monocyte chemotactic protein-1 by peripheral blood monocytes. F Pathol 1994;152:241-9.

5 Rollins BJ, Yoshimura T, Leonard EJ, et al. Cytokine activated human endothelial cells synthesize and secrete a monocyte chemoattractant MCP-1/JE. Am f Pathol 1991; monocyte chem

6 Nakamura H, Yoshimura K, Ari Jaffe H, et al. Interleukin-8 gene expression in human bronchial epithelial cells. $7 \mathrm{Biol}$ Chem 1991;266:19611-17. 
7 Standford TJ, Kunkel SL, Phan SH, et al. Alveolar macrophages-derived cytokines induce monocyte chemoattractant protein-1 expression from human pulmonary type II-like epithelial cells. F Biol Chem 1991;266:9912-18.

8 Bédard PA, Golds EE. Cytokine-induced expression of mRNAs for chemotactic factors in human synovial cells and fibroblasts. 7 Cell Physiol 1993:15:433-41.

9 Lukacs NW, Chensue SW, Smith RE, et al. Production of monocyte chemoattractant protein-1 and macrophage inflammatory protein-1 by inflammatory granuloma fibroblasts. Am F Pathol 1994;144: 711-18.

10 Colotta F, Sciacca FL, Sironi M, et al. Expression of monocyte chemotactic protein-1 by monocytes and endothelial cells exposed to thrombin. Am 7 Pathol 1994;144:975-85.

11 Mantovani A, Dejana E. Cytokines as communication signals between leukocytes and endothelial cells. Immunol Today 1989;10:370-5.

12 Matsuhima K, Morishita K, Yoshimura T, et al. Molecular cloning of human monocyte derived neutrophil chemotactic factor (MDNCF) and induction of MDNCF mRNA by tic factor (MDNCF) and induction of MDNCF mRNA by interleukin-1

13 Nelken NA, Coughin SR, Gordon D, et al. Monocyte chemoattractant protein-1 in human atheromatous plaques. $\mathcal{F}$ Clin Invest 1991;88:1121-7.

14 Carré PC, Mortenson RL, King TE Jr, et al. Increased expression of the interleukin-8 gene by alveolar macrophages in idiopathic pulmonary fibrosis. A potential mechanism for the recruitment and activation of the neutrophils in lung fibrosis. $\mathcal{F}$ Clin Invest $1991 ; \mathbf{8 8}: 1802-10$

15 Iyonaga $\mathrm{K}$, Takeya $\mathrm{M}$, Saita $\mathrm{N}$, et al. Monocyte chemoattractant protein-1 in idiopathic pulmonary fibrosis and other interstitial lung diseases. Hum Pathol 1994;25:45563.

16 Antony VB, Godbey SW, Kunkel SL, et al. Recruitment of inflammatory cells to the pleural space. F Immunol 1993;151:7216-23.

17 Koch AE, Kunkel SL, Harlow LA, et al. Enhanced production of monocyte chemoattractant protein-1 in rheumatoid tion of monocyte chemoattractant pro

18 van Meir E, Ceska M, Effenberger F, et al. Interleukin-8 is produced in neoplastic and infectious diseases of the human central nervous system. Cancer Res 1992:52:4299305.

19 Mazzucchelli L, Hauser C, Zgraggen K, et al. Differential in situ expression of the genes encoding the chemokines MCP-1 and RANTES in human inflammatory bowel disease. F Pathol 1996;178:201-6.

20 Graves DT, Barnhill R, Galanopoulos T, et al. Expression of monocyte chemotactic protein-1 in human melanoma in vivo. Am $\mathcal{F}$ Pathol 1992;140:9-14.

21 Zachariae COC, Anderson AO, Thompson AO, et al. Properties of monocyte chemotactic and activating factor (MCAF) purified from a human fibrosarcoma cell line. $\mathcal{F}$ Exp Med 1990;171:2177-82.
22 Bellocq A, Antoine M, Flahault A, et al. Neutrophil alveolitis in bronchioloalveoar carcinoma: induction by tumorderived interleukin-8 and relation to clinical outcome. Am Pathol 1998;152:83-92.

23 Kitadai Y, Haruma K, Sumii K, et al. Expression of interleukin-8 correlates with vascularity in human gastric carcinomas. Am f Pathol 1998;152:93-100.

24 Hsu S, Waldran JW, Hsu P, et al. Cytokines in malignant lymphomas. Hum Pathol 1993;24:1040-57.

25 Foss HD, Herbst $\mathrm{H}$, Gottstein S, et al. Interleukin-8 in Hodgkin's disease. Preferential expression by reactive cells and association with neutrophil density. Am F Pathol 1996; 148:1229-36.

26 Furutani Y, Nomura $\mathrm{H}$, Notake $\mathrm{M}$, et al. Cloning and sequencing of the cDNA for human monocyte chemotactic and activating factor (MCAF). Biochem Biophys Res Commun 1989;159:249-55.

27 Ruco LP, Stoppacciaro A, Pomponi D, et al. Immunoreactivity for IL-1 $\beta$ and TNF- $\alpha$ in human lymphoid and non-lymphoid tissues. Am f Pathol 1989;135:889-97.

28 Ruco LP, Pomponi D, Pigott R, et al. Cytokine production (IL- $1 \alpha$, IL- $1 \beta$ and TNF- $\alpha$ ) and endothelial cell activation (ELAM 1 and HLA-DR) in reactive lymphoadenitis, Hodgkin's disease and in non-Hodgkin's lymphomas. $A m \mathcal{F}$ Pathol 1990;137:1163-71.

29 Ruco LP, Pomponi D, Pigott R, et al. Expression and cell distribution of the intercellular adhesion molecule, vascular cell adhesion molecule, endothelial leukocyte adhesion molecule, and endothelial cell adhesion molecule (CD31) in reactive human lymph nodes and in Hodgkin's disease. Am 7 Pathol 1992;140:1337-44.

30 Girard JP, Springer TA. High endothelial venules (HEVs): specialized endothelium for lymphocyte migration. Immunol Today 1995;16:449-57.

31 Jiang Y, Beller DI, Friendl G, et al. Monocyte chemoattractant protein-1 regulates adhesion molecules expression and cytokine production in human monocytes. F Immunol 1992;148:2423-8.

32 Sozzani S, Luini W, Molino M, et al. The signal transduction pathway involved in the migration induced by a monocyte chemotactic cytokine. F Immunol 1991;147:2215-21.

33 Springer TA. Traffic signals for lymphocyte recirculation and leukocyte emigration: the multistep paradigm. Cell 1994;76:301-14.

34 Mantovani A. Tumor-associated macrophages in neoplastic progression: a paradigm for the in vivo function of chemokines. Lab Invest 1994;71:5-13.

35 Martinet N, Beck G, Bernard V, et al. Mechanism for the recruitment of macrophages to cancer site. Cancer 1992;70: $854-60$

36 Bottazzi B, Polentarutti N, Acero R, et al. Regulation of the macrophage content of neoplasms by chemoattractants. Science 1983;220:210-12. 